\title{
PROJECTING PRODUCTIVITY IN AGRICULTURE IN LATVIA
}

\author{
Aleksejs Nipers ${ }^{1}$, Agnese Krieviņa ${ }^{2}$, Irina Pilvere ${ }^{1}$ \\ ${ }^{1}$ Latvia University of Life Sciences and Technologies, Latvia \\ ${ }^{2}$ Institute of Agricultural Resources and Economics, Latvia \\ Aleksejs.Nipers@1lu.lv; Agnese.Krievina@arei.lv; Irina.Pilvere@1lu.lv
}

\begin{abstract}
The development of rural territories in the European Union (EU) plays an essential role, and agricultural development can largely contribute to this process. To project agricultural trends, a number of models have been developed in the EU, while in Latvia the LASAM model was developed in 2016 to generate projections for agricultural sector development in Latvia until 2050. In 2017, LASAM was extended by a module for socio-economic assessment that allows projecting productivity for various types of farming. The research aim is to develop a model for productivity simulation for various specialisation types of farms in order to project their development in Latvia. To achieve the aim, two specific research tasks were set: 1) to develop a model for productivity simulation for various specialisation types of farms in Latvia; 2) to identify the key results of the simulation of productivity for various specialisation types of farms in Latvia. The research found that in the period 2005 - 2016 the value added of agriculture tended to slightly increase in Latvia, whereas an opposite trend was observed for the number of persons employed in agriculture, which tended to decrease in the period of analysis. Both trends determine the agricultural productivity trend as well. A projection of productivity measured as value added per AWU for various farming types in Latvia by means of the LASAM model has revealed that it is different, and the highest level of productivity in 2030 and 2050 is projected for granivores as well as field crop farms.
\end{abstract}

Key words: projection, productivity, agriculture, types of farming.

\section{Introduction}

More than half of the population of the EU lives in predominantly or intermediate rural areas. These regions produce $45 \%$ of gross value added (GVA) and provide $53 \%$ of the employment of the EU-27. In land use terms, rural areas represent $93 \%$ of the EU-27 territory, with $20 \%$ of the population living in predominantly rural areas and $38 \%$ in significantly rural areas. Productivity is measured through two indicators: gross domestic product and GVA. The growth of GDP/capita in rural regions is higher than in urban regions since 2001, due to strong growth in the new Member States, especially from 2006 onwards. However, despite the positive trend that GDP/capita is increasing in rural areas, the gap between rural and urban is widening (ECORYS Nederland BV, 2010). These challenges create pressure on rural firms to increase productivity in order to be competitive with other firms that may be located closer to markets or have lower cost inputs near to them. Most importantly, for several decades rural regions have been impacted by the steady substitution of capital for labour in the natural resource sectors - agriculture, forestry, mining etc. that has increased productivity but reduced employment (OECD, 2015). The George Washington Institute (2011) stresses that we can grow the economy through increasing inputs or we can increase the productivity and efficiency of the regional economy (increase outputs per unit of input) - by improving the efficiency of market operations and governance; enhancing the interactions and synergies between different kinds of economic activity; and improving how the assets of the economy are organized and deployed spatially. Usually, technological change is an important driver of global food prices, as it directly affects productivity of land and production costs. However, the productivity increase is not sufficient to meet the doubling demand for agricultural products by 2050 without expansion of agricultural area (Frank et $a l ., 2014)$. Producing more with less, while preserving and enhancing the livelihoods of small-scale and family farmers, is a key challenge for the future (Food and Agriculture Organization, 2017). For a number of reasons, the agricultural productivity increase has gained renewed interest. The European Commission has launched an ambitious programme towards a resource efficient Europe in 2020. As a consequence, the agricultural sector is challenged to achieve more with less (European Commission, 2016a).

Agriculture develops dynamically in the EU, and the Common Agricultural Policy (CAP) regulates and determines opportunities for the growth of it. For this reason, both the European Commission and the governments of other Member States track the growth of the agriculture. On the one hand, the current situation is extensively analysed, while on the other hand, various models are developed to project the growth of agriculture. The most well-known and most employed models in the EU are as follows: CAPRI and AGLINK-COSIMO (Adenauer, 2008; Britz \& Witzke, 2012; Leip \& Eiselt, 2013), GLOBIOMEU (GLOBIOM model, 2012), AGMEMOD and ESIM (Antle, 2015; Grethe et al., 2012; Chantreuil, Salputra, \& Erjavec, 2013; Zeverte-Rivza, Nipers, \& Pilvere, 2017).

Therefore, the research aim is to develop a model for productivity simulation for various specialisation types of farms in order to project their development 
in Latvia. To achieve the aim, two specific research tasks were set: 1) to develop a model for productivity simulation for various specialisation types of farms in Latvia; 2) to identify the key results of the simulation of productivity for various specialisation types of farms in Latvia.

The object of the research is productivity on farms of various types of farming.

\section{Materials and Methods}

To generate projections for agricultural sector development in Latvia until 2050, Latvia University of Agriculture developed the LASAM model in 2016. LASAM is an econometric, recursive, dynamic, multi-period scenario model, which can also simulate GHG emissions. Most of the estimations within the model are done by performing linear regression, the regression models are evaluated by their statistical significance and the coefficient of determination (Nipers, Pilvere, \& Zeverte-Rivza, 2017). In 2017, the LASAM model was extended by a module for socioeconomic assessment that allows not only projecting and assessing the effects of policy measures on physical quantities produced in agriculture and its sectors but also analysing socio-economic effects (Zinātniskā pētījuma Lauksaimniecības ..., 2017). The present research shows a projection of productivity in agriculture.

Value added in the agricultural sector divided by size of the agricultural labour force should be an appropriate measure of agricultural productivity (Dorward, 2013). Value added is the value of output minus the value of goods and services used up in the production. Value added shows an increase in the market value of a product (Centrālā statistikas pārvalde, 2017a) that has arisen in the result of an economic activity. The value of goods and services used in the production for consumption, excluding fixed assets, the consumption of which is accounted for as fixed capital consumption, represents intermediate consumption (Centrālā statistikas pārvalde, 2017b).

Value added (at producer prices, excluding subsidies) and employment data for various types of farming were acquired orcalculated for theperiod 2005 2015 in Latvia from Farm Accountancy Data Network (FADN) (Datu bāze par.., 2016). Labour input in agriculture is measured in annual work units (AWU). One AWU corresponds to the work performed by one person who is occupied on an agricultural holding on a full-time basis (Eurostat, 2017b). An AWU is measured in man-years, and it is equal to 1840 hours (Institute of Agricultural Resources and Economics, 2017). The FADN is an instrument for evaluating the income of agricultural holdings and the impacts of the CAP. The rules applied aim to provide representative data for three criteria: region, economic size and type of farming. Types of farming at the level of the EU are: 1) field crops; 2) horticulture; 3) wine; 4) other permanent crops; 5) milk; 6) other grazing livestock; 7) granivores (pigs and poultry); 8) mixed (European Commission, 2017). Six of the above-mentioned types of farms are the most important for Latvia (excluding wine and mixed farming). The present research made a projection of productivity for five types of farming, as it was not possible to perform accurate projection calculations for other grazing livestock because this type of farms featured a very high level of intermediate consumption (in 2013-2015, 1.006, 0.974 and 0.925, respectively), while the projection of value added was performed without considering support payments (Zinātniskā pētījuma Lauksaimniecības ..., 2017).

\section{Results and Discussion}

Development of the model for productivity simulation for farms of various specialisation types in Latvia

The model computes value added per person employed based on FADN data on farms broken down by the specialisation type: field crops, vegetables, permanent crops, milk, as well as granivores (pigs and poultry)

A projection of value added per person employed by type of farming was made based on the projection of future value added per person employed, the present value of which was acquired from the FADN database.

A projection of value added per person employed for specialised field crop farms was made exogenously by analysing and comparing with the levels of other EU Member States.

A projection of value added per person employed for specialised vegetable farms was made based on a trend equation:

vegf_VA_AWU_vegfspec_reg $<-\operatorname{lm}($ vegf_VA AWU_vegfspec $\sim$ vegf_VA_AWU_vegfspec_trend) (1), where vegf_VA_AWU_vegfspec - value added per person employed in specialised vegetable farms; vegf_VA_AWU_vegfspec_trend - trend.

The intercept of the regression equation was computed at 3.66596 , coefficient $0.84895, \mathrm{p}=0.000$ (Table 1).

A projection of value added per person employed for specialised permanent crops farms was made based on a trend equation:

fr_VA_AWU_frspec_reg $<-1 \mathrm{~lm}(\mathrm{fr}$ _VA_AWU frspec $\sim$ fr_VA_AWU_frspec_trend) (2),

where fr_VA_AWU_frspec - value added per employed person for specialised permanent crop farms;

fr VA AWU frspec trend - trend.

The intercept of the regression equation was computed at 1.5469 , coefficient $0.5125, \mathrm{p}=0.029$ (Table 1). 


\section{Parameters of the regression equation for specialised vegetable and permanent crop farms} in Latvia in 2015

\begin{tabular}{|c|c|}
\hline \multicolumn{2}{|c|}{ Parameters of the regression equation } \\
\hline Vegetable farms & Permanent crop farms \\
\hline 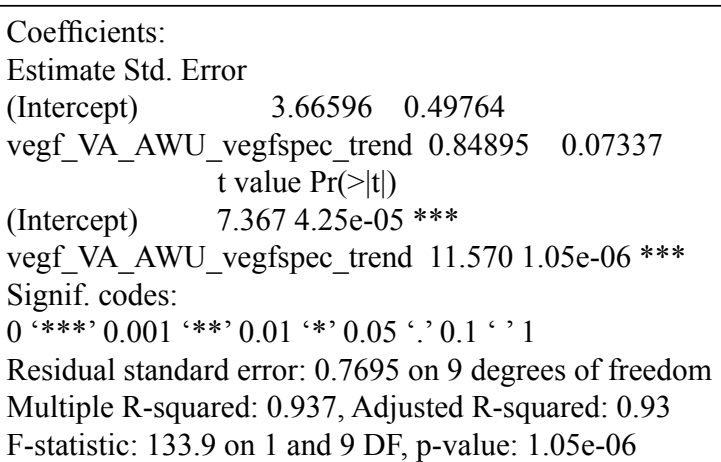 & 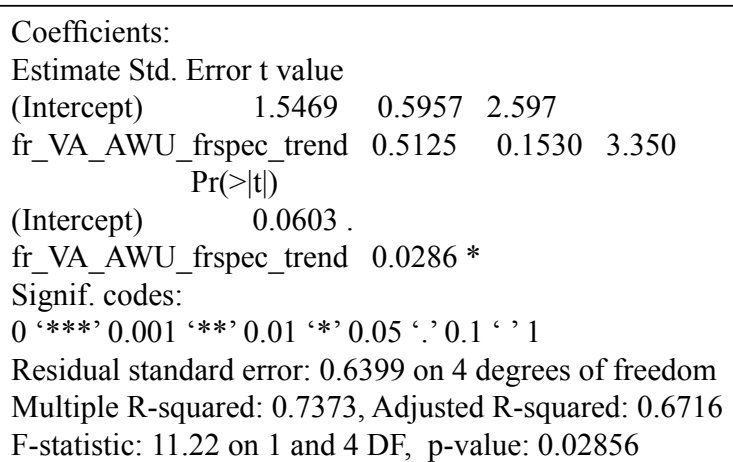 \\
\hline
\end{tabular}

Source: authors' calculations based on Datu bāze par ..., 2016; Zinātniskā pētījuma Lauksaimniecības ..., 2017.

A projection of value added per person employed for specialised dairy farms was made exogenously by analysing and comparing with the levels of other EU Member States.

A projection of target value added per person employed for specialised granivore farms was made based on a trend equation:

pp_VA_AWU_ppspec_reg<-lm(pp_VA_AWU_ ppspec $\sim$ pp_VA_AWU_ppspec_trend) (3),

where pp_VA_AWU_ppspec - value added per person employed for specialised granivore farms;

pp_VA_AWU_ppspec_trend - trend.

The intercept of the regression equation was computed at 6.571, coefficient 1.407, $\mathrm{p}=0.003$. The target value added acquired was exogenously equalised.

Key results of the simulation of productivity on farms of various specialisation types in Latvia

The EU-28 average farm net value added decreased by $5.8 \%$ from 2012 to 2013 , mainly due to the increase in the agricultural input costs (linked mainly to the increased costs of feeding stuffs and crop protection), while output value remained nearly unchanged (-1.3\%). The average farm net value added per annual work unit decreased by $4.6 \%$, from EUR 19000 in 2012 to EUR 18100 in 2013. On average, farms specialised in granivores, field crops, wine, milk and horticulture had the highest farm net value added per AWU, while the farm net value added per AWU of farms specialised in other permanent crops, grazing livestock (other than milk) and mixed activities remained below the EU-28 average (European Commission, 2016b). It has to be noted that farm net value added, which is a standard FADN indicator, slightly differs from the indicator used in the LASAM model (output minus intermediate consumption), yet development trends are possible to identify. Farm net value added takes into account subsidies and depreciation, while the LASAM model used derivative indicators in order to project the farm development easier.

According to the data from the Economic Accounts for Agriculture (EAA), a satellite account of the European system of national and regional accounts, adapted to the specific nature of the agricultural sector, providing complementary information and concepts (Eurostat, 2017a), in the period 2005 - 2016 in Latvia

Table 2

Parameters of the regression equation for specialised granivore farms in Latvia in 2015

\begin{tabular}{|c|c|}
\hline \multicolumn{2}{|c|}{ Parameters of the regression equation } \\
\hline 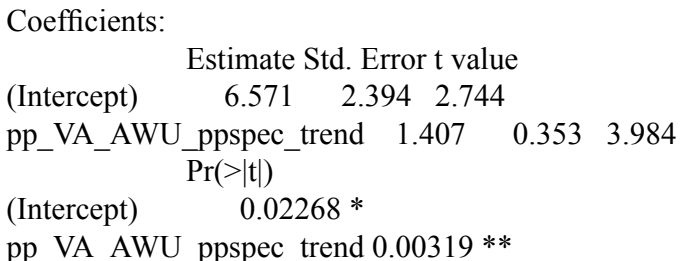 & $\begin{array}{l}\text { Signif. codes: } \\
0 \text { ‘***’ } 0.001 \text { '**' } 0.01 \text { '*' } 0.05 \text { ' }, 0.1 \text { ' ' } 1 \\
\text { Residual standard error: } 3.703 \text { on } 9 \text { degrees of freedom } \\
\text { Multiple R-squared: } 0.6382 \text {, Adjusted R-squared: } 0.598 \\
\text { F-statistic: } 15.87 \text { on } 1 \text { and } 9 \text { DF, p-value: } 0.003185\end{array}$ \\
\hline
\end{tabular}

Source: authors' calculations based on Datu bāze par ..., 2016; Zinātniskā pētījuma Lauksaimniecības ..., 2017. 


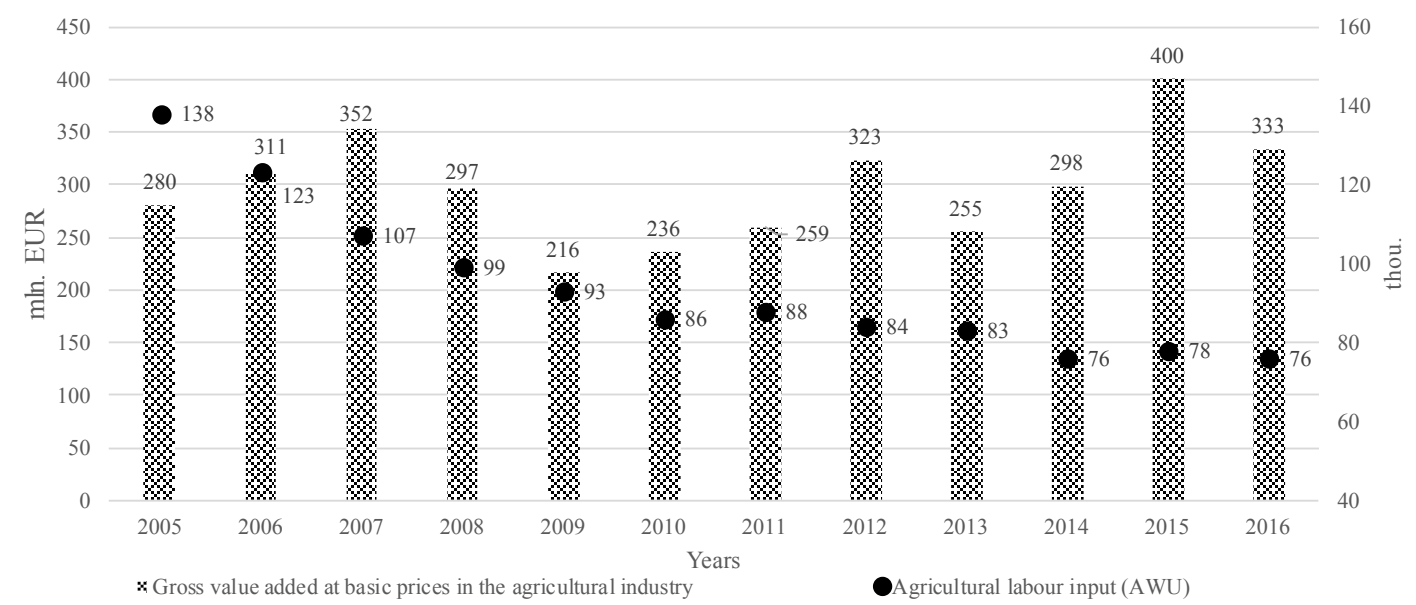

Source: Eurostat, 2017c.

Figure 1. Value added of the agricultural industry and the number of persons employed in agriculture in Latvia in the period $2005-2016$.

the value added of agricultural industry (at basic prices, including subsidies on agricultural products) increased from EUR 280 to 333 million (19\% increase), accounting for $2.2 \%$ and $1.4 \%$ of the total value added of the national economy and indicating a decrease in the significance of the agriculture in terms of value added and its share in GDP (Figure 1). The highest value added was reported in 2015 - EUR 400 million, while the lowest was during the global financial crisis in 2009 and 2010 - EUR 216 and 236 million, respectively. As regards agricultural employment, the number of employed persons in the analysed period decreased from 138 thousand in 2005 to 76 thousand In 2016, or by $45 \%$. Nevertheless, the number of employees in agriculture still makes up a significant share in the total number of employees in
Latvia - almost $9 \%$, which results in a considerably lower labour productivity level than in the national economy as a whole (authors' calculations based on LR Zemkopības ministrija, 2008; 2011; 2014; 2017). At a relatively steady volume of value added in recent years and a fast decrease in the number of persons employed in agriculture, the productivity level measured as value added per person employed gradually increased from EUR 2029 in 2005 to EUR 4382 in 2016 (2.2-fold increase), yet it still considerably falls behind the EU-28 average, which indicates opportunities for growth in the future.

For the needs of the simulation, value added at producer prices (support payments excluded) was used to compute the volume of value added per AWU in agriculture. The projection was made based
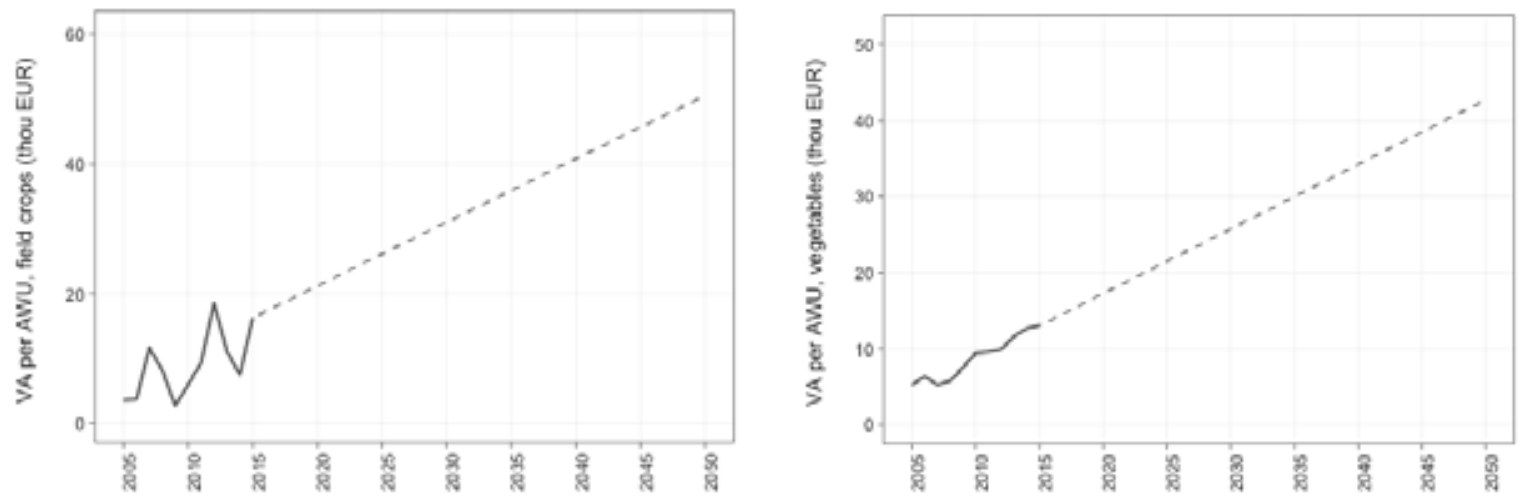

Source: authors' calculations based on Datu bāze par ..., Zinātniskā pētījuma Lauksaimniecības ..., 2017.

Figure 2. Value added per AWU on specialised field crop farms in the period $2005-2015$ and a projection of it in Latvia in the period 2016 - 2050, EUR thou.
Figure 3. Value added per AWU on specialised vegetable farms in the period $2005-2015$ and a projection of it in Latvia in the period 2016 - 2050, EUR thou. 

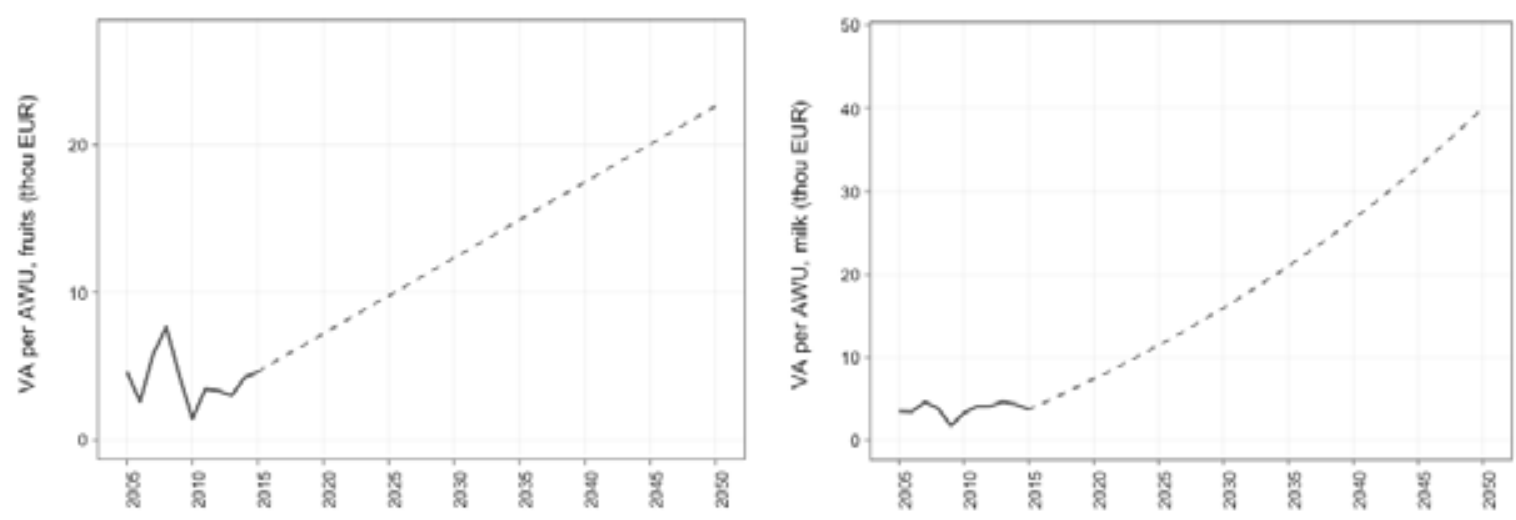

Source: authors' calculations based on Datu bāze par ..., Zinātniskā pētījuma Lauksaimniecības ..., 2017.

Figure 4. Value added per AWU on specialised permanent crop farms in the period $2005-2015$ and a projection of it in Latvia in the period 2016 2050, EUR thou.

on the FADN data, analysing the farms by their specialisation type.

The productivity is projected to considerably increase on specialised field crop farms owing to the farm concentration and intensification of the agricultural production. The value added per person employed is projected to reach EUR 31 thousand in 2030 and EUR 50.5 thousand in 2050, which is $69 \%$ and 2.8 times more than in 2017 (i.e. EUR 18.3 thousand) (Figure 2).

For comparison, in 2015 the value added per person employed on specialised field crop farms in other countries was significantly higher: EUR 41.2 thousand in Germany and Sweden, also EUR 38.0 thousand in Ireland and even EUR 93.3 thousand in the Netherlands (Zinātniskā pētījuma Lauksaimniecības ..., 2017). This means that a value added of EUR 50.5 thousand per person employed is an achievable target for field crop farms in Latvia.

Specialised vegetable farms demonstrated a steady increase in value added per person employed, and a similar increase is projected in the period up to 2050 (Figure 3). The current value added level in Latvia lags behind those in other EU Member States; for example, the value added per person employed in Germany was EUR 32.8 thousand, in the Netherlands - EUR 66.3 thousand (Zinātniskā pētījuma Lauksaimniecības ..., 2017). According to the projections produced by the LASAM model, the value added per person employed on specialised vegetable farms is expected to increase from EUR 14.7 thousand in 2017 to EUR 42.7 thousand in 2050 (2.9-fold increase). A considerable increase in productivity is projected for 2030 too - up to EUR 25.7 thousand per person employed $(+75 \%$ in comparison with 2017).

According to the projections, the value added per person employed on specialised permanent crop
Figure 5. Value added per AWU on specialised dairy farms in the period $2005-2015$ and a projection of it in Latvia in the period 2016 - 2050, EUR thou.

farms also has an increasing tendency (Figure 4). In 2017, the value added per person employed on specialised fruit farms was only EUR 5.6 thousand; it will increase to EUR 12.3 thousand in 2030 and to EUR 22.6 thousand in 2050 (4-fold increase in comparison with 2017).

In 2015, for comparison, the value added per person employed on specialised permanent crop farms in Germany was EUR 30.3 thousand and in Denmark - EUR 66.1 thousand (Zinātniskā pētījuma Lauksaimniecības ..., 2017).

According to the projections for dairy farming, an increase in productivity on specialised dairy farms is expected as well (Figure 5). However, unlike the trend in the value-added of the dairy sector, the value added per person employed is projected to increase after 2030, too, which will be promoted by production intensification. The projected increase in value added per person employed in the dairy farming is significant, as the current productivity level is low. In Latvia, it is projected to reach EUR 16 thousand in 2030 and EUR 40 thousand in 2050, which is 3 and 7.8 times higher than in 2017 (i.e. EUR 5.1 thousand).

For comparison, in 2015 the value added per person employed on specialised dairy farms in Germany was EUR 32.5 thousand, in Sweden - EUR 37.1 thousand, in Ireland - EUR 45.8 thousand, while in Denmark - even EUR 69.9 thousand (Zinātniskā pētījuma Lauksaimniecības ..., 2017).

Large intensive farms dominate among specialised granivore farms in Latvia; for this reason, a persistent increase in productivity is projected for this industry (Figure 6). Compared with EUR 22.5 thousand in 2017, the value added per person employed is projected to increase to EUR 45.3 thousand in 2030 (2-fold increase) and to EUR 67.7 thousand by 2050 (3-fold increase). 


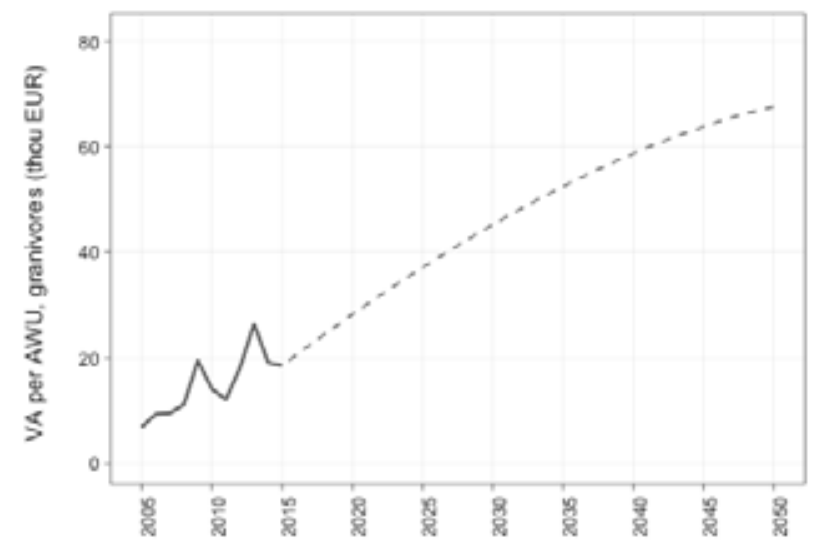

Source: authors' calculations based on Datu bāze par ..., 2016; Eurostat, 2017c; Zinātniskā pētījuma Lauksaimniecības ..., 2017.

Figure 6. Value added per AWU on specialised granivore farms in the period $2005-2015$ and a projection of it in Latvia in the period $2016-2050$, EUR thou.

In other countries, the value added per person employed on the farms of this specialisation type is relatively high. In 2015, it was EUR 41.3 thousand in Germany, EUR 74.8 thousand in Sweden, and EUR 83.0 thousand in Denmark (Zinātniskā pētījuma Lauksaimniecības ..., 2017).

The present and future increase trend of value added per person employed in Latvia is accompanied by decreasing agricultural employment. A similar situation is observed also in the EU as a whole where output growth has been achieved in a context of a shrinking workforce. Since 2005, the volume of agricultural output has increased by about $6 \%$, but this number is quite volatile given the economic, agronomic and climatic uncertainties characterizing agriculture. Between 2005 and 2015, the total workforce in agriculture declined with about $25 \%$ to around 9.6 million full time equivalents, in line with the restructuring in the direction of fewer, but larger farms (European Commission, 2016).

\section{Conclusions}

1. A number of models are employed to make projections for agriculture. In 2016 in Latvia, the LASAM model was developed to generate projections for agricultural sector developments in Latvia until 2050. In 2017, LASAM was extended by a module for socio-economic assessment that allows projecting productivity for various specialisation types of agricultural holdings.

2. The value added of agriculture increased by $19 \%$ in Latvia in the period 2005 - 2016. In 2016, it was $17 \%$ lower than in 2015 - the highest level reached in the period of analysis, yet the share of agriculture in the value added of the national economy decreased. The number of persons employed in agriculture in the period of analysis persistently decreased - from 138 thousand in 2005 to 76 thousand in 2016 - or by $45 \%$, yet it still makes up a significant share in the total number of employees in Latvia - almost 9\%. This trend contributes to increases in productivity in agriculture.

3. A projection of productivity measured as value added per AWU for farms of various specialisation types in Latvia revealed that the productivity varies, and it is affected by the currently achieved productivity level and the factors affecting the industry, yet there are prospects for an increase in productivity for the farms of all types:

$\checkmark$ productivity of specialised field crop farms is projected to increase to EUR 31 thousand in 2030 and EUR 50.5 thousand in 2050;

$\checkmark$ productivity of specialised vegetable farms is projected to increase to EUR 25.7 thousand in 2030 and EUR 42.7 thousand in 2050;

$\checkmark$ productivity of specialised permanent crop farms is projected to increase to EUR 12.3 thousand in 2030 and EUR 22.6 thousand in 2050;

$\checkmark$ productivity of specialised dairy farms is projected to increase to EUR 16 thousand in 2030 and EUR 40 thousand in 2050;

$\checkmark$ productivity of specialised granivore farms is projected to increase to EUR 45.3 thousand in 2030 and EUR 67.7 thousand in 2050.

\section{Acknowledgements}

The research was promoted with the support of the project of the Ministry of Agriculture of the Republic of Latvia "Forecasting of Agricultural Development and the Designing of Scenarios for Policies until 2050”, agreement No. 17-100-INV17-5-000023. 


\section{References}

1. Adenauer, M. (2008). CAPRI versus AGLINK-COSIMO Two Partial Equilibrium Models - Two Baseline Approaches. 12th Congress of the European Association of Agricultural Economists - EAAE 2008, p. 4.

2. Antle, J.M., Basso, B.O., Conant, R.T., Godfray, C., Jones, J.W., Herrero, M., Howitt, R.E., Keating, B.A., Munoz-Carpena, R., Rosenzweig, C., Tittonell, P., \& Wheeler, T.R. (2015). Model Design, Improvement and Implementation. In: Towards a New Generation of Agricultural System Models, Data, and Knowledge Products. Model Design, Improvement and Implementation, 31 January 2015, pp. 63 - 89.

3. Antle, J.M., Jones, J.W., \& Rosenzweig, C. (2015). Towards a New Generation of Agricultural System Models, Data, and Knowledge Products: Introduction. AgMIP, pp. 1-8. Retrieved January 4, 2018, from: http://goo.gl/MjNjHy.

4. Britz, W., \& Witzke, H.P. (2012). CAPRI Model Documentation 2012. In: CAPRI Model Documentation 2012, Bonn, University of Bonn.

5. Centrālā statistikas pārvalde (2017a). Pievienotā vērtība (uzṇēmējdarbības rādītāji) (Central Statistical Bureau. Value Added (structural business indicators)). Retrieved January 8, 2018, from: http://www.csb. gov.lv/statistikas-temas/termini/pievienota-vertiba-uznemejdarbibas-raditaji-37018.html. (in Latvian).

6. Centrālā statistikas pārvalde (2017b). Starppatēriņš (Central Statistical Bureau. Intermediate Consumption). Retrieved January 6, 2018, from: http://www.csb.gov.lv/statistikas-temas/termini/starppaterins-34386. html. (in Latvian).

7. Chantreuil, F., Salputra, G., \& Erjavec, E. (2013). Market Analysis of Direct Payment Options for New EU Member States Using the AGMEMOD Partial Equilibrium Modelling Tool. Outlook on AGRICULTURE, Vol. 42, No 1, pp. 33-40. DOI: 10.5367/oa.2013.0111.

8. Datu bāze par SUDAT saimniecībām (2016). Nepublicēts resurss (Database to FADN farms. Unpublished resource). (in Latvian).

9. Dorward, A. (2013). Agricultural labour productivity, food prices and sustainable development impacts and indicators. Food Policy, No 39, pp. 40-50.

10. ECORYS Nederland BV (2010). Study on Employment, Growth and Innovation in Rural Areas (SEGIRA). Main report, Rotterdam, 8 December 2010285 p.

11. European Commission (2016a). Productivity in EU agriculture - slowly but steadily growing. EU Agricultural Markets Briefs, No 10, December 2016, 19 p.

12. European Commission (2016b). EU Farm Economics Overview based on 2013 FADN data.

13. European Commission (2017). The Farm Accountancy Data Network. Concept of FADN. Retrieved January 14, 2018, from: http://ec.europa.eu/agriculture/rica/diffusion_en.cfm\#sg.

14. Eurostat (2017a). Glossary: Economic accounts for agriculture (EAA)

15. Eurostat (2017b). Glossary: Annual work unit (AWU). Retrieved January 12, 2018, from: http://ec.europa. eu/eurostat/statistics-explained/index.php/Glossary:Annual_work_unit_(AWU).

16. Eurostat (2017c). Agriculture. Data. Database. Economic accounts for agriculture (aact_eaa; aact_ali; aact uv). Retrieved October 12, 2017, from: http://ec.europa.eu/eurostat/web/agriculture/data/database.

17. Food and Agriculture Organization of the United Nations (2017). The future of food and agriculture Trends and challenges. Rome, $180 \mathrm{p}$.

18. Frank, S., Witzke, P., Zimmermann, A., Havlik, P., \& Ciaian, P. (2014). Climate Change Impacts on European Agriculture: A Multi Model Perspective. In: EAAE 2014 Congress Proceedings: Agri-Food and Rural Innovations for Healthier Societies, 26-29 August, 2014, Ljubljana, Slovenia, p. 15.

19. George Washington Institute of Public Policy and RW Ventures, LLC (2011). Implementing Regionalism: Connecting Emerging Theory and Practice to Inform Economic Development, November 2011, 248 p.

20. GLOBIOM model (2012). European Commission, Climate Analysis Models. Retrieved January 12, 2017 , from: https:/ec.europa.eu/clima/sites/clima/files/strategies/analysis/models/docs/globiom_en.pdf.

21. Grethe, H. (ed), Atavia, M., Banse, M., Boysen, O., Deppermann, A., \& Nolt, S. (2012). European Simulation Model (ESIM): Documentation (Model Code, Parameterization, Database), $101 \mathrm{p}$.

22. Institute of Agricultural Resources and Economics (2017). AGRICULTURAL HOLDINGS. RESULTS OF ECONOMIC ANALYSIS 2016, FADN (Farm Accountancy Data Network of Latvia), Riga, 83 p.

23. Leip, A., \& Eiselt, B. (2013). LUCAS and agri-environmental indicators for EU27, EC-JRC-IES EUROSTAT, 5 p.

24. LR Zemkopības ministrija (2008). Latvijas lauksaimniecība un lauki 2008 (Ministry of Agriculture of the Republic of Latvia. Agriculture and Rural Areas of Latvia 2008), 116 lpp. (in Latvian).

25. LR Zemkopības ministrija (2011). Latvijas lauksaimniecība 2011 (Ministry of Agriculture of the Republic of Latvia. Agriculture of Latvia 2012), 148 lpp. (in Latvian). 
26. LR Zemkopības ministrija (2014). Latvijas lauksaimniecība 2014 (Ministry of Agriculture of the Republic of Latvia. Agriculture of Latvia 2014), 156 lpp. (in Latvian).

27. LR Zemkopības ministrija (2017). Latvijas lauksaimniecība 2017 (Ministry of Agriculture of the Republic of Latvia. Agriculture of Latvia 2017), 170 lpp. (in Latvian).

28. Nipers, A., Pilvere, I., \& Zeverte-Rivza, S. (2017). Projections for the Latvian Dairy and Beef Sector In: 16th International Scientific Conference "Engineering for Rural Development": Proceedings, Jelgava, Latvia, May 24 - 26, 2017, Vol. 16, pp. 546-554. DOI: 10.22616/ERDev2017.

29. OECD Rural Policy Reviews (2015). New Rural Policy: LINKING UP FOR GROWTH, 36 p.

30. Zeverte-Rivza, S., Nipers, A., \& Pilvere, I. (2017). Agricultural Production and Market Modelling Approaches. In: Economic Science for Rural Development: Proceedings of the International Scientific Conference, Nr. 45: Integrated and Sustainable Regional Development. Marketing and Sustainable Consumption, Jelgava, pp. 267-274.

31. Zinātniskā pētījuma Lauksaimniecības attīstības prognozēšana un politikas scenāriju izstrāde līdz 2050. gadam projekta atskaite (Report on the Project Forecasting of Agricultural Development and the Designing of Scenarios for Policies until 2050) (2017). Jelgava: Latvia University of Agriculture, December 2017, 119 lpp. (in Latvian). 